\title{
Diosmectite-zinc oxide composite improves intestinal barrier function, modulates expression of pro-inflammatory cytokines and tight junction protein in early weaned pigs
}

\author{
Caihong Hu*, Juan Song, Yali Li, Zhaoshuang Luan and Kang Zhu \\ Animal Science College, Zhejiang University, The Key Laboratory of Molecular Animal Nutrition, Ministry \\ of Education, Hangzhou 310058, People's Republic of China \\ (Submitted 19 July 2012 - Final revision received 7 November 2012 - Accepted 11 November 2012 - First published online 11 January 2013)
}

\section{Abstract}

The study evaluated whether feeding diosmectite-ZnO composite (DS-ZnO) at $500 \mathrm{mg} \mathrm{Zn} / \mathrm{kg}$ to early weaned pigs would alleviate the weaning-related intestinal disorders as a substitute for high concentration of $\mathrm{ZnO}(2250 \mathrm{mg} \mathrm{Zn} / \mathrm{kg})$. The pigs weaned at an age of $21 \pm 1 \mathrm{~d}$ were allotted to four treatments groups as follows: (1) control; (2) DS-ZnO, $500 \mathrm{mg} \mathrm{Zn/kg} \mathrm{diet;} \mathrm{(3)} \mathrm{ZnO,} \mathrm{2250} \mathrm{mg} \mathrm{Zn/kg} \mathrm{diet;}$ and (4) mixture of $2 \cdot 0 \mathrm{~g} \mathrm{DS} / \mathrm{kg}$ and $500 \mathrm{mg} \mathrm{Zn} / \mathrm{kg}$ from $\mathrm{ZnO}$ (equal amount of DS and $\mathrm{ZnO}$ in the DS-ZnO treatment group). The results showed that, compared with the control on days 7 and 14 post-weaning, addition of DS-ZnO at $500 \mathrm{mg} \mathrm{Zn} / \mathrm{kg}$ improved $(P<0 \cdot 05)$ daily gain and feed intake, decreased $(P<0.05)$ post-weaning scour scores, increased $(P<0.05)$ jejunal villus height and the ratio of villus height and crypt depth, decreased $(P<0 \cdot 05)$ jejunal paracellular permeability of fluorescein isothiocyanate dextran $4 \mathrm{kDa}$ and up-regulated $(P<0.05)$ tight junction protein expression of occludin, claudin-1 and zonula occludens- 1 in jejunal mucosa. The mRNA levels of $T N F-\alpha, I L-6$ and interferon- $\gamma(I F N-\gamma)$ on day 7 post-weaning were also decreased $(P<0 \cdot 05)$. The piglets fed DS-ZnO at $500 \mathrm{mg} Z \mathrm{Zn} / \mathrm{kg}$ did not differ in the above parameters from those fed $\mathrm{ZnO}$ at $2250 \mathrm{mg} \mathrm{Zn} / \mathrm{kg}$, while they had better performance than those fed the mixture of DS and $\mathrm{ZnO}$. Supplementation with $\mathrm{DS}-\mathrm{ZnO}$ at $500 \mathrm{mg} \mathrm{Zn/kg}$ was effective in alleviating diarrhoea, barrier dysfunction and inflammatory cytokine expression and up-regulating tight junction protein expression.

\section{Key words: Diosmectite-zinc oxide composite: Intestinal barrier: Pro-inflammatory cytokines: Tight junction protein:}

\section{Weaned pigs}

The early weaning process is commonly associated with intestinal barrier dysfunction and mucosal inflammation in weaned piglets, which are responsible for the stunted growth and diarrhoea observed in the first 2 weeks after weaning $^{(1-3)}$. $\mathrm{Zn}$ is involved in anti-inflammation, antidiarrhoea and restoration of mucosal barrier integrity ${ }^{(4,5)}$. Pharmacological addition of $\mathrm{Zn}(2000-4000 \mathrm{mg} / \mathrm{kg}$ of $\mathrm{Zn}$ as $\mathrm{ZnO}$ ) in diets for weaned pigs is widely used in the pig industry worldwide due to its proven effects on alleviating post-weaning diarrhoea and improving performance ${ }^{(3,6)}$. However, high levels of $\mathrm{ZnO}$ in diets for weaner pigs has been criticised or banned because increased $\mathrm{Zn}$ excretion causes environmental pollution ${ }^{(3,7)}$. If the inclusion of $\mathrm{ZnO}$ is dramatically decreased and if the same effect as that of high levels of $\mathrm{ZnO}$ is achieved, then the $\mathrm{Zn}$ excretion will decrease and will be beneficial for sustaining swine production.
Diosmectite (DS) is an aluminosilicate clay mineral, which is composed of two outer tetrahedral silicon layers sandwiching an inner octahedral aluminum layer. Naturally occurring cations (i.e. $\mathrm{Na}^{+}$) reside between the sheets to balance the overall negative surface charge of $\mathrm{DS}^{(8)}$. The ion exchange capacity of DS enables replacement of $\mathrm{Na}^{+}$with other organic and inorganic cations to add functionality, spurring research into the use of DS as a controlled-release carrier for various active ingredients in drug delivery systems ${ }^{(8-10)}$. DS intercalated by drug molecules delays and/or targets drug release, increases drug stability and modifies drug delivery patterns ${ }^{(11)}$ On the other hand, DS can reinforce the intestinal mucosal barrier and epithelial regeneration ${ }^{(12)}$. It has anti-inflammatory and anti-diarrhoeal effects in rats, human subjects and pigs $^{(13-15)}$

$\mathrm{ZnO}$ acts largely within the gastrointestinal tract, as the majority of ingested $\mathrm{Zn}$ is excreted in faeces ${ }^{(16)}$. Controlling

Abbreviations: DS, diosmectite; DS-ZnO, diosmectite-ZnO composite; EGF, epidermal growth factor; FD4, fluorescein isothiocyanate dextran $4 \mathrm{kDa}$; IFN- $\gamma$, interferon- $\gamma$; TER, transepithelial electrical resistance; ZO-1, zonula occludens-1; TJ, tight junction. 
at least ten well-oriented crypt-villus units using image analysis (Leica Imaging Systems Limited) and averaged for each sample.

\section{Ex vivo Ussing chamber to measure intestinal barrier function}

Ussing chamber procedures were performed as described by Hamard et $a l{ }^{(21)}$. Briefly, segments of jejunum were stripped from the seromuscular layer in oxygenated $\left(95 \% \mathrm{O}_{2} / 5 \%\right.$ $\mathrm{CO}_{2}$ ) Ringer's solution and then mounted in the EasyMount Ussing chamber system with a multi-channel voltage-current clamp (model VCC MC6; Physiologic Instruments). They were bathed on each side with a bicarbonate Ringer's solution, with $10 \mathrm{~mm}$-glucose and $10 \mathrm{~mm}$-mannitol on the serosal and mucosal sides, respectively, and maintained at $37^{\circ} \mathrm{C}$. The clamps were connected to Acquire and Analyse software (Physiologic Instruments) for automatic data collection. After a 30-min equilibration period on the Ussing chambers, TER $\left(\Omega \mathrm{cm}^{2}\right)$ and short-circuit current $\left(\mu \mathrm{A} / \mathrm{cm}^{2}\right)$ were recorded at $15-\mathrm{min}$ intervals over a 2 - $h$ period and then averaged to derive the TER values for a given pig. FD4 (Sigma-Aldrich) was added on the mucosal side at a final concentration of $0.375 \mathrm{mg} / \mathrm{ml}$. Mucosal-to-serosal flux of FD4 (ng/ $\mathrm{cm}^{2}$ per h) was monitored by sampling $100 \mu \mathrm{l}$ of solution from the serosal side at 30-min intervals for $120 \mathrm{~min}$. The concentrations of FD 4 in the serosal side were measured by fluorescence microplate reader (FLx800; Bio-Tek Instruments, Inc.). The flux over the 2-h period was calculated.

\section{Pro-inflammatory cytokine mRNA by real-time PCR}

Relative mRNA abundance of $T N F-\alpha, I L-6$ and interferon- $\gamma$ $(I F N-\gamma)$ in jejunal mucosa was determined by real-time PCR, as described by Liu et al. ${ }^{(22)}$. Briefly, total RNA was extracted using the TRIzol reagent (Invitrogen) and treated with DNase I (Invitrogen Life Technologies) following the manufacturer's guidelines. To amplify complementary DNA fragments, the following sequences of PCR primer were used: forward 5'-ATGGTGAAGGTCGGAGTGAAC- $3^{\prime}$, reverse 5'-CTCGCTCCTGGAAGATGGT-3' for glyceraldehyde-3-phosphate dehydrogenase (235 bp); forward 5' - CATCGCCGTCTCCTACCA- $3^{\prime}$, reverse $5^{\prime}$-CCCAGATTCAGCAAAGTCCA- $3^{\prime}$ for TNF- $\alpha$ (199 bp); forward $5^{\prime}$-GAGCCAAATTGTCTCCTTCTAC$3^{\prime}$, reverse 5'-CGAAGTCATTCAGTTTCCCAG-3' for IFN- $\gamma$ (140 bp); and forward $5^{\prime}$-CCTGTCCACTGGGCACATAAC- $3^{\prime}$, reverse 5'-CAAGAAACAACCTGGCTCTGAAAC- $3^{\prime}$ for IL-6 (253 bp). Quantitative real-time RT-PCR was performed on a StepOne Plus real-time PCR system (Applied Biosystems) using a SYBR Green Master mix (Promega), according to the kit's instructions. Gene-specific amplification was determined by melting curve analysis and agarose gel electrophoresis. Each sample was run in triplicate. The average $C_{\mathrm{t}}$ was calculated for pro-inflammatory cytokine and GAPDH and the $\Delta C_{\mathrm{t}}\left(C_{\mathrm{t}}\right.$, cytokine- $\left.C_{\mathrm{t}}, \mathrm{GAPDH}\right)$ was determined, where $C_{\mathrm{t}}$ is the number of cycles required to reach an arbitrary threshold. The $2^{-\Delta \Delta C_{\mathrm{t}}}$ method $^{(23)}$ was used to analyse the relative expression (fold changes), calculated relative to the control group on day 7 post-weaning.

\section{Tight junction protein immunoblot analysis}

TJ protein expressions of zonula occludens-1 (ZO-1), occludin and claudin-1 were measured by Western blotting, as described by Ewaschuk et al. ${ }^{(24)}$. Briefly, the total protein was extracted as directed by the instructions of a total protein extraction kit (Keygen Biotech). Equal amounts of protein from each treatment $(20 \mu \mathrm{g})$ were separated by SDS-PAGE on $7 \cdot 5 \%$ (ZO-1) and $10 \%$ (claudin-1 and occludin) polyacrylamide gels. Proteins were electrophoretically transferred to polyvinylidene difluoride membranes (Millipore) The following primary antibodies were used: rabbit polyclonal anti-claudin-1 (1:300; Santa Cruz Biotechnology), rabbit polyclonal anti-occludin (1:450; Santa Cruz Biotechnology) and rabbit polyclonal anti-ZO-1 (1:400; Santa Cruz Biotechnology). Blots were also probed with anti-actin antibodies. The secondary antibody was horseradish peroxidase-conjugated anti-rabbit antibody (Santa Cruz Biotechnology). An enhanced chemiluminescence detection kit (Amersham) was used to detect the positive bands. Densitometric analysis for protein bands were carried out using ImageQuant software (Molecular Dynamics). The value of protein expression was the ratio of the densitometry units of TJ protein and $\beta$-actin. The control sample on day 7 post-weaning was used as the reference sample. The protein expression of all samples was expressed as fold changes, calculated relative to the control group on day 7 post-weaning.

\section{Statistical analysis}

Data were analysed using the SAS statistical package (version 8.1; SAS Institue) ${ }^{(25)}$. A pen of pigs served as the experimental unit for all data. Differences among means were tested using Duncan's multiple range tests. Differences were considered significant at $P<0.05$.

\section{Results}

\section{Growth performance and post-weaning scour scores}

Table 2 shows the growth performance and post-weaning scour scores of newly weaned pigs. As compared with the control, dietary addition of DS-ZnO at $500 \mathrm{mg} \mathrm{Zn/kg} \mathrm{or} \mathrm{ZnO}$ at $2250 \mathrm{mg} \mathrm{Zn} / \mathrm{kg}$ improved $(P<0.05)$ average daily gain and average daily feed intake and decreased $(P<0.05)$ faecal scores on both days $0-7$ post-weaning and days $7-14$ postweaning. The weaned piglets fed DS-ZnO at $500 \mathrm{mg} \mathrm{Zn/kg}$ did not differ in average daily gain, average daily feed intake and post-weaning scour scores from those fed $\mathrm{ZnO}$ at $2250 \mathrm{mg} \mathrm{Zn} / \mathrm{kg}(P>0.05)$, while they had better performance than those fed the mixture of equal amount of DS and $\mathrm{ZnO}$. Supplementation with the mixture of DS and $\mathrm{ZnO}$ had no effect on post-weaning scour scores of piglets.

\footnotetext{
The 2 $\Delta \Delta c_{1}$ method 23 was used to analyse the relative
} 
Table 2. Efficacy of diosmectite-zinc oxide composite (DS-ZnO) on growth performance and post-weaning scour scores of weanling pigs

(Mean values with their standard errors)

\begin{tabular}{|c|c|c|c|c|c|}
\hline & Control & $\mathrm{DS}+\mathrm{ZnO}^{*}$ & $\begin{array}{l}500 \mathrm{mg} \mathrm{Zn} / \mathrm{kg} \\
\text { as DS-ZnO† }\end{array}$ & $\begin{array}{c}2250 \mathrm{mg} \mathrm{Zn} / \mathrm{kg} \\
\text { as ZnO }\end{array}$ & SEM \\
\hline \multicolumn{6}{|c|}{ Days $0-7$ post-weaning } \\
\hline ADG $(\mathrm{g})$ & $155^{\mathrm{b}}$ & $163^{\mathrm{b}}$ & $182^{\mathrm{a}}$ & $178^{\mathrm{a}}$ & 4.8 \\
\hline ADFI $(g)$ & $186^{\mathrm{b}}$ & $195^{\mathrm{b}}$ & $216^{a}$ & $214^{a}$ & $6 \cdot 0$ \\
\hline Gain:feed (g/kg) & 833 & 836 & 843 & 832 & 22.5 \\
\hline Faecal scores & $3.97^{\mathrm{a}}$ & $3.75^{\mathrm{a}}$ & $1 \cdot 81^{\mathrm{b}}$ & $1 \cdot 61^{\mathrm{b}}$ & 0.12 \\
\hline \multicolumn{6}{|c|}{ Days $7-14$ post-weaning } \\
\hline ADG $(\mathrm{g})$ & $307^{c}$ & $317^{\mathrm{b}, \mathrm{c}}$ & $344^{\mathrm{a}}$ & $337^{a, b}$ & $8 \cdot 1$ \\
\hline ADFI $(g)$ & $397^{\mathrm{b}}$ & $406^{a, b}$ & $434^{a}$ & $430^{\mathrm{a}}$ & $10 \cdot 8$ \\
\hline Gain:feed (g/kg) & 773 & 781 & 793 & 784 & $18 \cdot 1$ \\
\hline Faecal scores & $2.53^{\mathrm{a}}$ & $2 \cdot 32^{\mathrm{a}}$ & $1 \cdot 30^{\mathrm{b}}$ & $1.41^{\mathrm{b}}$ & 0.08 \\
\hline
\end{tabular}

$A D G$, average daily gain; ADFI, average daily feed intake.

a,b,c Mean values within a row with unlike superscript letters were significantly different $(P<0.05)$.

* Supplemental mixture of $2.0 \mathrm{~g} \mathrm{DS} / \mathrm{kg}$ diet and $500 \mathrm{mg} \mathrm{Zn/kg} \mathrm{diet} \mathrm{from} \mathrm{ZnO} \mathrm{(equal} \mathrm{amount} \mathrm{of} \mathrm{DS} \mathrm{and} \mathrm{ZnO} \mathrm{in} \mathrm{the} \mathrm{DS-ZnO} \mathrm{group).}$

†DS-ZnO, DS-ZnO composite, containing $250 \mathrm{~g} \mathrm{Zn/kg} \mathrm{DS-ZnO.}$

\section{Jejunal morphology of weaned piglets}

Table 3 shows jejunal morphology of piglets on days 7 and 14 post-weaning. Supplementation with DS-ZnO at $500 \mathrm{mg} \mathrm{Zn/kg}$ or $\mathrm{ZnO}$ at $2250 \mathrm{mg} \mathrm{Zn} / \mathrm{kg}$ had both higher $(P<0.05)$ villus height and the ratio of villus height and crypt depth at the jejunal mucosa, as compared with the control. The weaned piglets fed DS-ZnO at $500 \mathrm{mg} \mathrm{Zn/kg} \mathrm{did} \mathrm{not} \mathrm{differ} \mathrm{in} \mathrm{jejunal}$ morphology from those fed $\mathrm{ZnO}$ at $2250 \mathrm{mg} \mathrm{Zn} / \mathrm{kg}$ $(P>0.05)$, while they had higher $(P<0.05)$ villus height and the ratio of villus height and crypt depth on day 7 postweaning than those fed the mixture of DS and $\mathrm{ZnO}$. Supplemental mixture of DS and $\mathrm{ZnO}$ had no $(P>0.05)$ effect on jejunal morphology.

\section{Intestinal barrier function}

Table 4 shows the intestinal barrier function of piglets on days 7 and 14 post-weaning, which was reflected by TER and paracellular flux of FD4 measured in the Ussing chambers. As compared with the control, dietary addition of DS-ZnO at $500 \mathrm{mg} \mathrm{Zn/kg}$ or $\mathrm{ZnO}$ at $2250 \mathrm{mg} \mathrm{Zn/kg} \mathrm{decreased}$ $(P<0.05)$ FD 4 flux on both days 7 and 14 post-weaning. The piglets fed DS-ZnO at $500 \mathrm{mg} \mathrm{Zn/kg} \mathrm{did} \mathrm{not} \mathrm{differ} \mathrm{in}$ FD4 flux from those fed $\mathrm{ZnO}$ at $2250 \mathrm{mg} \mathrm{Zn/kg}(P>0 \cdot 05)$, while they had lower $(P<0.05)$ FD 4 flux than those fed the mixture of DS and ZnO. Supplemental mixture of DS and $\mathrm{ZnO}$ had no $(P>0.05)$ effect on jejunal barrier function of weaned pigs. The TER and short-circuit current were not affected by dietary treatments $(P>0 \cdot 05)$.

\section{Pro-inflammatory cytokine mRNA}

The mRNA levels of $T N F-\alpha, I L-6$ and $I F N-\gamma$ in jejunal mucosa on days 7 and 14 post-weaning are presented in Table 5. As compared with control, supplementation with DS-ZnO at $500 \mathrm{mg} \mathrm{Zn} / \mathrm{kg}$ or $\mathrm{ZnO}$ at $2250 \mathrm{mg} \mathrm{Zn/kg} \mathrm{both} \mathrm{decreased}$ $(P<0 \cdot 05)$ mucosal mRNA of TNF- $\alpha, I L-6$ and $I F N-\gamma$ on day 7 post-weaning. The piglets fed DS-ZnO at $500 \mathrm{mg} \mathrm{Zn/kg} \mathrm{did}$ not differ in cytokine mRNA from those fed $\mathrm{ZnO}$ at $2250 \mathrm{mg}$ $\mathrm{Zn} / \mathrm{kg}(P>0.05)$, while they had lower $(P<0.05)$ mRNA levels of TNF- $\alpha$ and $I L-6$ on day 7 post-weaning compared with those fed the mixture of DS and ZnO. The mRNA levels of $T N F-\alpha, I L-6$ and $I F N-\gamma$ on day 14 post-weaning were not affected by dietary treatments.

\section{Tight junction protein expression}

Fig. 1 shows the protein expression levels of occludin, claudin-1 and ZO-1 in jejunal mucosa on days 7 and 14

Table 3. Effects of diosmectite-zinc oxide (DS-ZnO) on jejunal morphology of weanling pigs

(Mean values with their standard errors)

\begin{tabular}{|c|c|c|c|c|c|}
\hline & Control & $\mathrm{DS}+\mathrm{ZnO}^{*}$ & $\begin{array}{l}500 \mathrm{mg} \mathrm{Zn} / \mathrm{kg} \\
\text { as DS-ZnO† }\end{array}$ & $\begin{array}{l}2250 \mathrm{mg} \mathrm{Zn} / \mathrm{kg} \\
\text { as ZnO }\end{array}$ & SEM \\
\hline \multicolumn{6}{|l|}{ On day 7 post-weaning } \\
\hline Villus height $(\mu \mathrm{m})$ & $676^{\mathrm{b}}$ & $723^{b}$ & $806^{a}$ & $817^{a}$ & $25 \cdot 7$ \\
\hline Crypt depth $(\mu \mathrm{m})$ & 382 & 368 & 351 & 347 & $12 \cdot 5$ \\
\hline Villus height:crypt depth & $1.77^{\mathrm{b}}$ & $1.96^{b}$ & $2 \cdot 30^{\mathrm{a}}$ & $2 \cdot 35^{a}$ & 0.08 \\
\hline \multicolumn{6}{|l|}{ On day 14 post-weaning } \\
\hline Villus height $(\mu \mathrm{m})$ & $761^{\mathrm{b}}$ & $785^{a, b}$ & $845^{a}$ & $830^{a, b}$ & $26 \cdot 9$ \\
\hline Crypt depth $(\mu \mathrm{m})$ & 364 & 352 & 336 & 345 & $11 \cdot 9$ \\
\hline Villus height:crypt depth & $2.09^{c}$ & $2 \cdot 23^{\mathrm{b}, \mathrm{c}}$ & $2 \cdot 51^{a}$ & $2 \cdot 41^{\mathrm{a}, \mathrm{b}}$ & 0.09 \\
\hline
\end{tabular}

${ }^{a, b, c}$ Mean values within a row with unlike superscript letters were significantly different $(P<0.05)$.

* Supplemental mixture of $2.0 \mathrm{~g} \mathrm{DS} / \mathrm{kg}$ diet and $500 \mathrm{mg} \mathrm{Zn} / \mathrm{kg}$ diet from ZnO (equal amount of DS and ZnO in the DS-ZnO group).

†DS-ZnO, DS-ZnO composite, containing $250 \mathrm{~g} \mathrm{Zn/kg} \mathrm{DS-ZnO.}$ 
Table 4. Effect of diosmectite-zinc oxide (DS-ZnO) on jejunal barrier function of weanling pigs

(Mean values with their standard errors)

\begin{tabular}{|c|c|c|c|c|c|}
\hline & Control & $\mathrm{DS}+\mathrm{ZnO}^{*}$ & $\begin{array}{l}500 \mathrm{mg} \mathrm{Zn} / \mathrm{kg} \\
\text { as DS-ZnO† }\end{array}$ & $\begin{array}{l}2250 \mathrm{mg} \mathrm{Zn} / \mathrm{kg} \\
\text { as ZnO }\end{array}$ & SEM \\
\hline \multicolumn{6}{|l|}{ On day 7 post-weaning } \\
\hline $\operatorname{TER}\left(\Omega \mathrm{cm}^{2}\right)$ & $50 \cdot 7$ & 53.4 & $56 \cdot 2$ & $54 \cdot 3$ & $2 \cdot 80$ \\
\hline FD4 flux $\left(\mu \mathrm{g} / \mathrm{cm}^{2}\right.$ per $\left.\mathrm{h}\right)$ & $2 \cdot 46^{\mathrm{a}}$ & $2 \cdot 18^{a}$ & $1.61^{\mathrm{b}}$ & $1.45^{\mathrm{b}}$ & 0.13 \\
\hline Isc $\left(\mu \mathrm{A} / \mathrm{cm}^{2}\right)$ & $13 \cdot 0$ & $13 \cdot 2$ & $12 \cdot 7$ & $12 \cdot 5$ & 0.34 \\
\hline \multicolumn{6}{|l|}{ On day 14 post-weaning } \\
\hline $\operatorname{TER}\left(\Omega \mathrm{cm}^{2}\right)$ & 52.5 & 54.5 & $58 \cdot 7$ & $59 \cdot 2$ & 3.02 \\
\hline FD4 flux $\left(\mu \mathrm{g} / \mathrm{cm}^{2}\right.$ per $\left.\mathrm{h}\right)$ & $2 \cdot 03^{a}$ & $1 \cdot 82^{\mathrm{a}}$ & $1 \cdot 23^{b}$ & $1 \cdot 31^{\mathrm{b}}$ & 0.12 \\
\hline Isc $\left(\mu \mathrm{A} / \mathrm{cm}^{2}\right)$ & 11.1 & $10 \cdot 8$ & $10 \cdot 4$ & 10.5 & 0.36 \\
\hline
\end{tabular}

TER, transepithelial electrical resistance; FD4, fluorescein isothiocyanate dextran $4 \mathrm{kDa}$; Isc, short-circuit current.

${ }^{a, b}$ Mean values within a row with unlike superscript letters were significantly different $(P<0.05)$.

* Supplemental mixture of $2.0 \mathrm{~g} \mathrm{DS} / \mathrm{kg}$ diet and $500 \mathrm{mg} \mathrm{Zn/kg}$ diet from ZnO (equal amount of DS and ZnO in the DS-ZnO group).

†DS-ZnO, DS-ZnO composite, containing $250 \mathrm{~g} \mathrm{Zn/kg} \mathrm{DS-ZnO.}$

post-weaning. As compared with control, supplementation with DS-ZnO at $500 \mathrm{mg} \mathrm{Zn/kg}$ or $\mathrm{ZnO}$ at $2250 \mathrm{mg} \mathrm{Zn/kg}$ both increased $(P<0.05)$ protein expression levels of occludin, claudin-1 and ZO-1 on day 7 post-weaning, and protein expression of occludin and ZO-1 on day 14 postweaning. The piglets fed DS-ZnO at $500 \mathrm{mg} \mathrm{Zn} / \mathrm{kg}$ did not differ in TJ proteins expression from those fed $\mathrm{ZnO}$

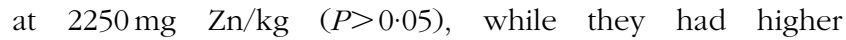
$(P<0.05)$ protein expression levels of occluding and ZO-1 compared with those fed the mixture of DS and $\mathrm{ZnO}$. Supplemental mixture of DS and $\mathrm{ZnO}$ had no $(P>0.05)$ effect on TJ proteins' expression.

\section{Discussion}

Early weaned piglets frequently encounter growth impairment and post-weaning diarrhoea, which induce major economic losses for pig producers ${ }^{(2,3)}$. The importance of $\mathrm{Zn}$ in the treatment of acute and persistent diarrhoea is well-known ${ }^{(5)}$. The addition of a high concentration of $\mathrm{ZnO}$ to the weaning diet (between 2000 and $4000 \mathrm{mg} / \mathrm{kg}$ of $\mathrm{Zn}$ as $\mathrm{ZnO}$ ) alleviates post-weaning diarrhoea and increases growth, although the mechanisms underlying these effects have not been fully illuminated $^{(3,6,16)}$. In the present study, supplementation with
$\mathrm{ZnO}$ at $2250 \mathrm{mg} \mathrm{Zn/kg} \mathrm{in} \mathrm{weaned} \mathrm{pigs} \mathrm{improved} \mathrm{feed} \mathrm{intake}$ and growth and decreased post-weaning diarrhoea, which is consistent with previous reports. The increased feed intake might have beneficial effects on the barrier function and inflammation, as weaning anorexia may contribute to local inflammation in the piglet small intestine ${ }^{(26)}$.

In the present experiment, a supplemental mixture of $2.0 \mathrm{~g}$ $\mathrm{DS} / \mathrm{kg}$ and $500 \mathrm{mg} \mathrm{Zn} / \mathrm{kg}$ had no influence on post-weaning diarrhoea, inflammation and intestinal barrier function. In contrast to our findings, it was reported that DS was effective in anti-diarrhoea, anti-inflammation and intestinal mucosal restoration in human subjects and pigs ${ }^{(13-15)}$. DS may adhere to gastrointestinal mucous membranes and reinforce the physical mucous barrier ${ }^{(12)}$. Its anti-diarrhoeal mechanisms involve adsorption of toxins and bacteria, modifications of mucus rheological properties and modulatory action of cytokine production $^{(13,14)}$. The possible reason for the ineffectiveness of DS in the present experiment may be that the inclusion of DS $(2 \cdot 0 \mathrm{~g} / \mathrm{kg})$ was too low. The dosage of DS in anti-diarrhoeal remedy was suggested to be $20-30 \mathrm{~g} / \mathrm{kg}^{(15)}$. Gonzalez et $a l .{ }^{(13)}$ found that the anti-inflammatory effect of DS was dose-dependent. The present result, that supplementation with $\mathrm{ZnO}$ at $500 \mathrm{mg} \mathrm{Zn} / \mathrm{kg}$ had no influence on growth performance and post-weaning diarrhoeal of

Table 5. Relative mRNA levels of pro-inflammatory cytokines in jejunal mucosa of piglets*

(Mean values with their standard errors)

\begin{tabular}{|c|c|c|c|c|c|}
\hline & Control & $\mathrm{DS}+\mathrm{ZnO}+$ & $\begin{array}{c}500 \mathrm{mg} \mathrm{Zn} / \mathrm{kg} \\
\text { as DS-ZnO }\end{array}$ & $\begin{array}{c}2250 \mathrm{mg} \mathrm{Zn} / \mathrm{kg} \\
\text { as ZnO }\end{array}$ & SEM \\
\hline \multicolumn{6}{|c|}{ On day 7 post-weaning } \\
\hline TNF- $\alpha$ & $1 \cdot 00^{\mathrm{a}}$ & $0.69^{a}$ & $0.20^{\mathrm{b}}$ & $0.28^{\mathrm{b}}$ & 0.12 \\
\hline IL-6 & $1.00^{\mathrm{a}}$ & $0.81^{a}$ & $0.34^{\mathrm{b}}$ & $0.30^{\mathrm{b}}$ & 0.15 \\
\hline Interferon- $\gamma$ & $1.00^{\mathrm{a}}$ & $0.77^{\mathrm{a}, \mathrm{b}}$ & $0.41^{\mathrm{b}}$ & $0.32^{\mathrm{b}}$ & 0.16 \\
\hline \multicolumn{6}{|c|}{ On day 14 post-weaning } \\
\hline TNF- $\alpha$ & 0.36 & 0.25 & 0.26 & 0.20 & 0.07 \\
\hline IL-6 & 0.25 & 0.31 & 0.28 & 0.36 & 0.11 \\
\hline Interferon- $\gamma$ & 0.24 & 0.27 & 0.35 & 0.21 & $0.0 \mathrm{~s}$ \\
\hline
\end{tabular}

DS-ZnO, diosmectite- $\mathrm{ZnO}$ composite.

${ }^{a, b}$ Mean values within a row with unlike superscript letters were significantly different $(P<0.05)$.

${ }^{*}$ The $2^{-\Delta \Delta C_{t}}$ method was used to analyse the relative expression (fold changes), calculated relative to the control group on day 7 post-weaning. Data are means of six pigs, each in triplicate.

† Supplemental mixture of $2.0 \mathrm{~g} \mathrm{DS} / \mathrm{kg}$ diet and $500 \mathrm{mg} \mathrm{Zn/kg} \mathrm{diet} \mathrm{from} \mathrm{ZnO} \mathrm{(equal} \mathrm{amount} \mathrm{of} \mathrm{DS} \mathrm{and} \mathrm{ZnO} \mathrm{in} \mathrm{the} \mathrm{DS-ZnO} \mathrm{group).}$

$\ddagger D S-Z n O, D S-Z n O$ composite, containing $250 \mathrm{~g} \mathrm{Zn/kg} \mathrm{DS-ZnO.}$ 
(A)
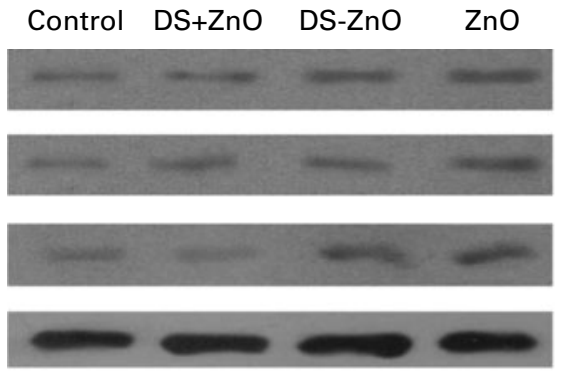

Occludin

Claudin-1

ZO-1

$\beta$-Actin

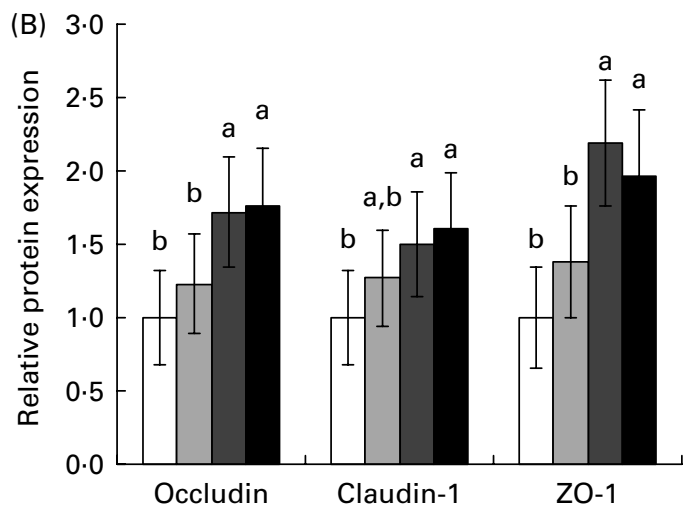

(C)
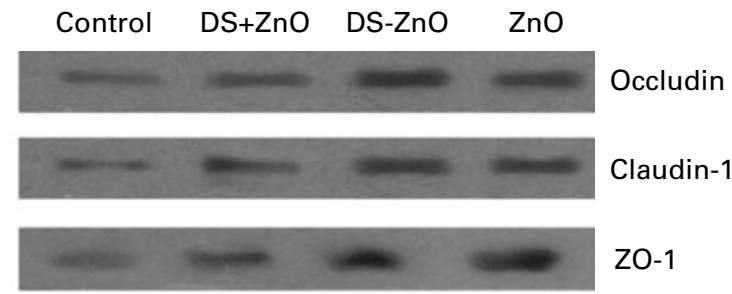

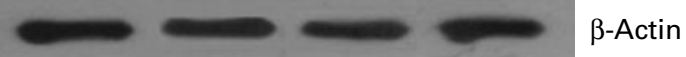

Fig. 1. Relative tight junction protein expressions in jejunal mucosa of piglets. (A) and (C) are representative blots of occludin, claudin, zonula occludens-1 (ZO-1) and $\beta$-actin on days 7 and 14 post-weaning, respectively. (B) and (D) show relative tight junction proteins expression on days 7 and 14 post-weaning, respectively. Values are means and standard deviations represented by vertical bars. ${ }^{\text {a,b,c }}$ Mean values with unlike letters were significantly different $(P<0.05)$. DS-ZnO, diosmectite-zinc oxide composite, containing $250 \mathrm{~g}$ zinc $/ \mathrm{kg} \mathrm{DS}-\mathrm{ZnO}$. DS $+\mathrm{ZnO}$, mixture of $2.0 \mathrm{~g} \mathrm{DS} / \mathrm{kg}$ diet and $500 \mathrm{mg}$ zinc/kg diet from zinc oxide (equal amount of DS and zinc oxide in the DS-ZnO group). The value of protein expression was the ratio of the densitometry units of tight junction protein and $\beta$-actin. The control sample on day 7 post-weaning was used as the reference sample. The protein expression of all samples was expressed as fold changes, calculated relative to the control group on day 7 post-weaning. $\square$, Control; $\square, \mathrm{DS}+\mathrm{ZnO}$; $\square, \mathrm{DS}-\mathrm{ZnO}$; $\mathbf{\square}, \mathrm{ZnO}$.

piglets, was consistent with previous research. Davis et al. ${ }^{(27)}$ found that supplementing $\mathrm{ZnO}$ to provide 500 parts per million $\mathrm{Zn}$ in weanling pig diets did not result in any benefit. Hollis et al. ${ }^{(28)}$ reported no growth improvement when supplementing $\mathrm{ZnO}$ at levels less than $1000 \mathrm{mg} / \mathrm{kg}$ in weanling pigs.

To decrease inclusion of $\mathrm{ZnO}$ and to achieve the same effect of high levels of $\mathrm{ZnO}$, we used DS as a controlledrelease carrier for $\mathrm{ZnO}$ delivery. DS has been researched as an effective drug delivery carrier for controlled-release of bioactive molecules, drugs and nutrients, such as epidermal growth factor $(\mathrm{EGF})^{(8)}$, ibuprofen ${ }^{(9)}$ and vitamin $\mathrm{B}_{6}{ }^{(10)}$. In the present study, we functionalised DS with $\mathrm{ZnO}$ via ion exchange reaction to create a composite (DS-ZnO). Khaorapapong et $a l .{ }^{(17)}$ found that $\mathrm{ZnO}$ was located between the interlayer space and on the surface of DS. The present experiment demonstrated that the growth performance and post-weaning diarrhoea of weaned piglets fed DS-ZnO at $500 \mathrm{mg} \mathrm{Zn/kg}$ was comparable with those fed $\mathrm{ZnO}$ at $2250 \mathrm{mg} \mathrm{Zn/kg}$, while significantly better than those fed the equivalent amount of the mixture of DS and $\mathrm{ZnO}$. Zheng et al. ${ }^{(9)}$ intercalated ibuprofen into DS to synthesise an ibuprofen/DS composite as a drug release system. The in vitro release experiment showed that the release of ibuprofen from the ibuprofen/DS composite in simulated intestinal fluid was markedly higher than that in simulated gastric fluid. Vaiana et al. ${ }^{(8)}$ used DS as a delivery mechanism for EGF and found that the DS-EGF composite
(D) 3.5

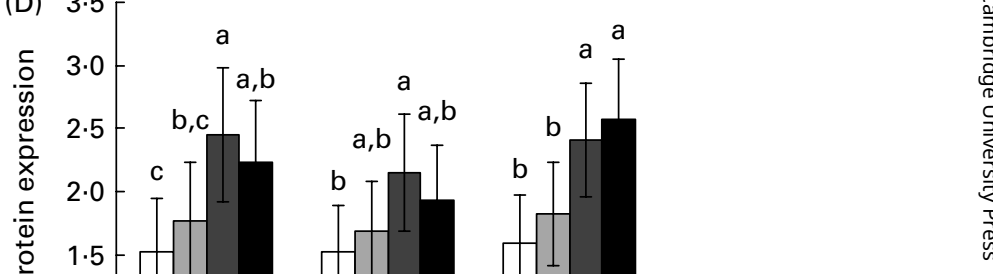

enhanced both the haemostatic and the proliferative stages of epithelial wound healing. They observed a strong bond between EGF and DS after several days of incubation in complete media, suggesting that DS-EGF remains largely intact. Controlling the release of $\mathrm{ZnO}$ in the gastrointestinal tract may improve its effectiveness ${ }^{(3)}$. A lipid-coated $\mathrm{ZnO}$ has been claimed to prevent the absorption or chemical change of $\mathrm{ZnO}$ in the stomach, allowing it to enter the upper intestine where the lipid coating is broken down by lipase enzymes ${ }^{(3)}$. This releases the $\mathrm{ZnO}$ in the critical area of the gastrointestinal tract for maximum effectiveness ${ }^{(3)}$. DS served as a controlled-release carrier that might modify the rate and site of $\mathrm{ZnO}$ release. However, a better understanding of the binding and release properties of DS- $\mathrm{ZnO}$ is needed to fully characterise the mechanism of DS- $\mathrm{ZnO}$.

Compromising alterations in villus-crypt structure are common in weaned pigs. Weaning is associated with villus atrophy and crypt hyperplasia ${ }^{(3,29)}$. The shorter villus and deeper crypt observed in the control treatment verified the deterioration of intestinal morphology induced by weaning. Dietary inclusion of $\mathrm{DS}-\mathrm{ZnO}$ at $500 \mathrm{mg} \mathrm{Zn} / \mathrm{kg}$ or $\mathrm{ZnO}$ at $2250 \mathrm{mg} \mathrm{Zn/kg}$ reduced the weaning-associated damage to small intestinal morphology. The small-intestinal epithelium serves as a barrier against noxious antigens and pathogens. Impaired intestinal barrier function may increase the translocation of intestinal bacteria and the entering of toxic 
or allergenic substances from the gut into the body ${ }^{(2)}$. It has been reported that the early weaning process is associated with intestinal barrier dysfunction of piglets ${ }^{(2,3,30)}$. $\mathrm{Zn}$ supplementation improved mucosal repair in rats with experimental colitis $^{(31)}$, and reduced intestinal permeability in children with acute diarrhoea and persistent diarrhoea syndromes $^{(5)}$. However, little data are available regarding the addition of pharmacological doses of $\mathrm{ZnO}$ on intestinal permeability in weaned pigs. In the present experiment, the ex vivo Ussing chamber was used to monitor intestinal permeability. The flux of intact FD4 across the intestinal epithelium occurs mainly through paracellular pathways ${ }^{(21)}$. An increased flux of FD 4 reflects an impaired intestinal barrier. Supplementation with DS-ZnO at $500 \mathrm{mg} \mathrm{Zn/kg}$ or $\mathrm{ZnO}$ at $2250 \mathrm{mg} \mathrm{Zn} / \mathrm{kg}$ reduced the paracellular flux of FD4 across the epithelium, indicating that the intestinal barrier function of weaned pigs was improved. Our findings are similar to another study ${ }^{(32)}$, which used urinary recovery of lactulose and mannitol to assess paracellular permeability and reported that addition of $\mathrm{ZnO}$ at $2000 \mathrm{mg} \mathrm{Zn} / \mathrm{kg}$ decreased intestinal permeability of weaned piglets.

Weaning-associated intestinal inflammation and activation of the mucosal immune system have been described in the weanling rat $^{(33)}$. Pié et al. $^{(1)}$ also reported the up-regulated expression of pro-inflammatory cytokines in the intestine in newly weaned pigs. Over-production of pro-inflammatory cytokines has an adverse effect on intestinal mucosal integrity $^{(22)}$. Recent studies have indicated that most proinflammatory cytokines, such as TNF- $\alpha$, IFN- $\gamma$, IL- $1 \beta$ and IL-6, induce a pathologic opening of the intestinal TJ barrier and increase intestinal epithelial permeability ${ }^{(34)}$. The cytokine TNF- $\alpha$ can act synergistically with INF- $\gamma$ to induce structural changes in $\mathrm{TJ}^{(35)}$. Controlling the release of intestinal pro-inflammatory cytokines may have potential benefits in alleviating gut disorders induced by weaning stress ${ }^{(22)}$. In vitro, $\mathrm{ZnO}$ reduced inflammatory response of porcine epithelial IPEC J2 cells to enterotoxigenic Escherichia coli infection $^{(4)}$, and counteracted the up-regulated expression of the inflammatory $I L-8, T N F-\alpha$ mRNA levels caused by $E$. coli $\mathrm{K}_{88}$ using Caco-2 enterocytes ${ }^{(35)}$. In the present study, dietary addition of DS-ZnO at $500 \mathrm{mg} \mathrm{Zn/kg}$ or $\mathrm{ZnO}$ at $2250 \mathrm{mg} \mathrm{Zn/kg}$ decreased mucosal mRNA of TNF- $\alpha, I L-6$ and $I F N-\gamma$ on day 7 post-weaning, while it did not affect pro-inflammatory cytokine mRNA on day 14 post-weaning. It has been demonstrated that weaning is associated with a transient up-regulation of inflammatory cytokine mRNA content on days 3 to 4 post-weaning, and that the levels of most cytokines rapidly return to pre-weaning values after day 9 post-weaning ${ }^{(1)}$. This might be why the mRNA levels of $T N F-\alpha, I L-6$ and $I F N-\gamma$ on day 14 post-weaning were not affected by the dietary treatments in the present study. The down-regulation of pro-inflammatory cytokine on day 7 post-weaning in the presence of DS-ZnO indicated that weaning-induced inflammation was minimised. It has also been shown that activation of mast cells and release of mast cell proteases play a major role in the intestinal barrier dysfunction during the post-weaning period ${ }^{(36)}$. Furthermore, Ou et al. ${ }^{(37)}$ suggest a link between $\mathrm{ZnO}$ and mast cells in the porcine gut.
The intestinal barrier is mainly formed by a layer of epithelial cells joined together by $\mathrm{TJ}^{(38)}$. $\mathrm{TJ}$ consist mainly of the transmembrane protein complexes (e.g. claudins and occludins) and the cytosolic proteins $\mathrm{ZO}$ (e.g. junctional adhesion molecule, ZO-1, ZO-2 and ZO-3) ${ }^{(3)}$. These proteins form a structure at the boundary of two adjacent cells, working as a barrier within the epithelial cell space. The TJ proteins are the rate-limiting step in the paracellular pathway and form a selectively permeable barrier ${ }^{(38)}$. The early weaning-induced up-regulation of pro-inflammatory cytokine might elicit alterations of $\mathrm{TJ}$ protein expression, because pro-inflammatory cytokine have been shown to down-regulate TJ protein expression $^{(34)}$. The present study indicated that supplementation with DS-ZnO increased the protein expression of ZO-1, claudin-1 and occludin.

Overall, the results demonstrated that the weaned piglets fed DS-ZnO at $500 \mathrm{mg} \mathrm{Zn/kg} \mathrm{did} \mathrm{not} \mathrm{differ} \mathrm{in} \mathrm{growth} \mathrm{perform-}$ ance, post-weaning diarrhoea and intestinal barrier function from those fed $\mathrm{ZnO}$ at $2250 \mathrm{mg} \mathrm{Zn} / \mathrm{kg}$, while they had better performance than those fed the equivalent amount of mixture of DS and ZnO. Dietary inclusion of DS-ZnO at $500 \mathrm{mg} \mathrm{Zn/kg}$ may alleviate diarrhoea and improve intestinal barrier function by down-regulation of pro-inflammatory cytokines and up-regulation of $\mathrm{TJ}$ proteins.

\section{Acknowledgements}

This research was jointly supported by the National Natural Science Foundation of China (grant no. 31072039), the Zhejiang Provincial Natural Science Foundation (no. Z3100071), the '948' Project from the Ministry of Agriculture (no. 2011-G7), the Program for Changjiang Scholars and Innovative Research Team in University (no. IRT1040). C. H. designed research; C. H., J. S., Y. L., Z. L. and K. Z. conducted the experiment and analysed the data; C. H. and J. S. wrote the paper. C. H. had primary responsibility for the final content. There are no financial or personal conflicts of interest to report.

\section{References}

1. Pié S, Lallès JP, Blazy F, et al. (2004) Weaning is associated with an upregulation of expression of inflammatory cytokines in the intestine of piglets. J Nutr 134, 641-647.

2. Wijtten PJA, Meulen J \& Verstegen MWA (2011) Intestinal barrier function and absorption in pigs after weaning: a review. Br J Nutr 105, 967-981.

3. Kim JC, Hansen CF, Mullana BP, et al. (2012) Nutrition and pathology of weaner pigs: nutritional strategies to support barrier function in the gastrointestinal tract. Anim Feed Sci Technol 173, 3-16.

4. Sargeant HR, Miller HM \& Shaw MA (2011) Inflammatory response of porcine epithelial IPEC J2 cells to enterotoxigenic $E$. coli infection is modulated by zinc supplementation. Mol Immunol 48, 2113-2121.

5. Patel A, Mamtani M, Dibley MJ, et al. (2010) Therapeutic value of zinc supplementation in acute and persistent diarrhea: a systematic review. PLOS ONE 5, e10386. 
6. Hahn JD \& Baker DH (1993) Growth and plasma zinc responses of young pigs fed pharmacologic levels of zinc. J Anim Sci 71, 3020-3024.

7. Poulsen HD \& Larsen T (1995) Zinc excretion and retention in growing pigs fed increasing levels of zinc oxide. Livest Prod Sci 43, 235-242.

8. Vaiana CA, Leonard MK, Drummy LF, et al. (2011) Epidermal growth factor: layered silicate nanocomposites for tissue regeneration. Biomacromolecules 12, 3139-3146.

9. Zheng JP, Luan L, Wang HY, et al. (2007) Study on ibuprofen/montmorillonite intercalation composites as drug release system. Appl Clay Sci 36, 297-301.

10. Joshi GV, Patel HA, Bajaj HC, et al. (2009) Intercalation and controlled release of vitamin $\mathrm{B}_{6}$ from montmorillonite-vitamin $\mathrm{B}_{6}$ hybrid. Colloid Polym Sci 287, 1071-1076.

11. Aguzzi C, Cerezo P, Viseras C, et al. (2007) Use of clays as drug delivery systems: possibilities and limitations. Appl Clay Sci 36, 22-36.

12. Droy-Lefaix MT, Drouet Y \& Schatz B (1985) Sodium glycodeoxycholate and spinability of gastrointestinal mucus-protective effect of smectite. Gastroenterology $\mathbf{8 8}$, $1369-1369$.

13. Gonzalez R, Sanchez de Medina F, Martinez-Augustin O, et al. (2004) Anti-inflammatory effect of diosmectite in hapteninduced colitis in the rat. Br J Pharmacol 141, 951-960.

14. Dupont C \& Vernisse B (2009) Anti-diarrheal effects of diosmectite in the treatment of acute diarrhea in children: a review. Pediatr Drugs 11, 89-99.

15. Song M, Liu Y, Soares JA, et al. (2012) Dietary clays alleviate diarrhea of weaned pigs. J Anim Sci 90, 345-360.

16. Sargeant HR, McDowall KJ, Miller HM, et al. (2010) Dietary zinc oxide affects the expression of genes associated with inflammation: transcriptome analysis in piglets challenged with ETEC $\mathrm{K}_{88}$. Vet Immunol Immunopathol 137, 120-129.

17. Khaorapapong N, Khumchoo N \& Ogawa M (2011) Preparation of zinc oxide-montmorillonite hybrids. Mater Lett 65, 657-660.

18. Hu CH, Song J, You ZT, et al. (2012) Zinc oxidemontmorillonite hybrid influences diarrhea, intestinal mucosal integrity, and digestive enzyme activity in weaned pigs. Biol Trace Elem Res 149, 190-196.

19. Hur SG, Kim TW, Hwang SJ, et al. (2006) Heterostructured nanohybrid of zinc oxide-montmorillonite clay. J Phys Chem B 110, 1599-1604.

20. National Research Council (1998) Nutrient Requirements of Swine, 10th ed. Washington, DC: National Academy Press.

21. Hamard A, Mazurais D, Boudry G, et al. (2010) A moderate threonine deficiency affects gene expression profile, paracellular permeability and glucose absorption capacity in the ileum of piglets. J Nutr Biochem 21, 914-921.

22. Liu YL, Huang JJ, Hou YQ, et al. (2008) Dietary arginine supplementation alleviates intestinal mucosal disruption induced by Escherichia coli lipopolysaccharide in weaned pigs. Br J Nutr 100, 552-560.

23. Livak KJ \& Schmittgen TD (2001) Analysis of relative gene expression data using real-time quantitative PCR and $2^{-\Delta \Delta C_{\mathrm{t}}}$ method. Methods 25, 402-408.
24. Ewaschuk JB, Murdoch GK, Johnson IR, et al. (2011) Glutamine supplementation improves intestinal barrier function in a weaned piglet model of Escherichia coli infection. Br J Nutr 106, 877-877.

25. SAS Institute, Inc. (2000) SAS/STAT User's Guide, Version 8.1. Cary, NC: SAS Institute, Inc.

26. McCracken BA, Spurlock ME, Roos MA, et al. (1999) Weaning anorexia may contribute to local inflammation in the piglet small intestine. J Nutr 129, 613-619.

27. Davis ME, Brown DC, Maxwell CV, et al. (2004) Effect of phosphorylated mannans and pharmacological additions of zinc oxide on growth and immunocompetence of weanling pigs. J Anim Sci 82, 581-587.

28. Hollis GR, Carter SD, Cline TR, et al. (2005) Effects of replacing pharmacological levels of dietary zinc oxide with lower dietary levels of various organic zinc sources for weanling pigs. J Anim Sci 83, 2123-2129.

29. Montagne L, Boudry G, Favier C, et al. (2007) Main intestinal markers associated with the changes in gut architecture and function in piglets after weaning. BrJ Nutr 97, 45-57.

30. Smith F, Clark JE, Overman BL, et al. (2010) Early weaning stress impairs development of mucosal barrier function in the porcine intestine. Am J Physiol Gastrointest Liver Physiol 298, G352-G363.

31. Sturniolo GC, Fries W, Mazzon E, et al. (2002) Effect of zinc supplementation on intestinal permeability in experimental colitis. J Lab Clin Med 139, 311-315.

32. Zhang BK \& Guo YM (2009) Supplemental zinc reduced intestinal permeability by enhancing occluding and zonula occludens protein-1 (ZO-1) expression in weaning piglets. Br J Nutr 102, 687-693.

33. Cummins AG, Steele TW, LaBrooy JT, et al. (1988) Maturation of the rat small intestine at weaning: changes in the epithelial cell kinetics, bacterial flora, and mucosal immune activity. Gut 29, 1672-1679.

34. Al-Sadi R, Boivin M \& Ma T (2009) Mechanism of cytokine modulation of epithelial tight junction barrier. Front Biosci 14, 2765-2778.

35. Roselli M, Finamore A, Garaguso I, et al. (2003) Zinc oxide protects cultured enterocytes from the damage induced by Escherichia coli. J Nutr 133, 4077-4082.

36. Moeser AJ, Ryan KA, Nighot PK, et al. (2007) Gastrointestinal dysfunction induced by early weaning is attenuated by delayed weaning and mast cell blockade in pigs. $A m \mathrm{~J}$ Physiol Gastrointest Liver Physiol 293, G413-G421.

37. Ou DY, Li DF, Cao YH, et al. (2007) Dietary supplementation with zinc oxide decreases expression of the stem cell factor in the small intestine of weanling pigs. J Nutr Biochem $\mathbf{1 8}$, $820-826$.

38. Li X, Akhtar S \& Choudhry MA (2012) Alteration in intestine tight junction protein phosphorylation and apoptosis is associated with increase in IL-18 levels following alcohol intoxication and burn injury. Biochim Biophys Acta 1822, 196-203.

39. Feed Database in China (2011) Table of Feed Composition and Nutritive Value in China, 22th ed. Beijing: China Feed. 